ERIC S. NELSON

\title{
INTRODUCTION: \\ ONTO-HERMENEUTICS, ETHICS, AND NATURE IN THE YIJING
}

The essays gathered here are a sample of the ways in which the Yijing 《易經》can be approached. They explore the onto-hermeneutical and generative character of change in the Yijing (Chung-ying Cheng), the relation between traditional metaphysics and contemporary physics (Andreas Schöter), the interpretations of the Yijing in the Twofold Mystery Daoism of the early Tang dynasty (Friederike Assandri) and in modern European philosophy (Eric Nelson), and the Yijing's significance for contemporary American life and culture (Joseph Grange).

There are, it is said, as many ways of interpreting the Yijing as there are individuals interpreting it. This multiplicity of perspectives hangs together suggesting a contextual whole through which each is elucidated and, in turn, an elucidation of the whole through multiplicity. The Yijing is hermeneutical in disclosing the mutuality and interdependence of the particular and the whole in the moment (shi 時). The Yijing's hermeneutics is far from being a disinterested observer's art of reading texts and tracing authorial intentions for the sake of historical reconstruction. This "onto-hermeneutics" involves the Yijing's practitioner's participation in and performative enactment of cosmos, society, and self. ${ }^{1}$

The Yijing is ordinarily interpreted as a text and practice of divination ( $b u$ 卜). Divination is a controversial category in Western modernity, given the rejection of divination for prophecy in the Torah, and the deepening of this distrust in later Abrahamic traditions. Divination is also dismissed in dominant narratives about modern science, since it apparently poses an obstacle to the goal of disenchanting and demystifying the world by explaining it through efficient material causes. Notwithstanding such doubts, the Yijing retains its fascination, and this appeal transcends standard-favorable or antagonistic — understandings of divination.

ERIC S. NELSON, Associate Professor, Department of Philosophy, University of Massachusetts Lowell. Specialties: Chinese, comparative, European philosophy. E-mail: eric_nelson@uml.edu

Journal of Chinese Philosophy 38:3 (September 2011) 335-338

(C) 2011 Journal of Chinese Philosophy 
Part of its appeal is that the Yijing oversteps the conventional construal of divination. The Yijing does not deny the natural world for a supernatural realm but "naturalistically" recognizes and affirms the contingent and transient causal character of the world, revealing an immanent balance, harmony, and order within it. The Yijing is more than a way of making predictions based on contingent combinations of affairs, images, and concepts. It indicates in the interpretative situation multiple ontologies or ways of disclosing the cadences, rhythms, and threads running through the transformation of the myriad things.

The Yijing is not a theory about nature. It enacts a philosophy of nature in which its interpreters are called to interpret, recognize, and appropriately respond to things, others, and the self from out of their own circumstances. This responsive recognition to the contextual whole of life is not only conceptual but affective, drawing on the whole individual in the particularity of her or his life. The words, images, and interpretive practices of the Yijing are not calculative and self-interested, features of divination highlighted by its detractors, as their logic and import are onto-cosmological, aesthetic, and ethical. The Yijing calls its practitioners to self-reflection and interpretation in relation to their natural, social, and individual worlds. In the constant change and infinite variety of the world, it indicates its harmony (he 和) and the individual's interpretive co-agency in this balancing and rebalancing of the world.

To consider one example:

di zhong you shan, qian; jun zi yi pou duo yi gua, cheng wu ping shi 地中有山, 謙; 君子以衰多益寡, 稱物平施。2

The image of "the mountain in the earth" (di zhong you shan 地中有山) is not only an ontological lesson in the play of concealment and unconcealment. The mountain in the earth is interpreted ethically as addressing the noble person ( junzi 君子) to be humble or modest (qian 謙) by attending to the lonely and destitute (the "gua 寡”); that is, to act for the widow, orphan, and childless elder, for the poor and the needy. Such exemplary nobility of character does not mean an excess of generosity remaining above and detached from the other's abjection. Nobility is a humility that restores harmony and balance by "humbling the mighty and raising the destitute" (pou duo yi gua 衰多益寡).

Based in the Judaic understanding of the evils of divination and the glory of prophecy, Emmanuel Levinas distinguished the "subjective and arbitrary divination of the future" from "the extraordinary phenomenon of prophetic eschatology" that concerns the ethical priority of the other. ${ }^{3}$ Adopting Levinas's distinction, this and other passages from the Yijing do not concern divination-interpreted as a self- 
interested and instrumental calculation about the future based on subjective opinion and preference-but prophecy in calling for responsiveness such as humility toward the destitute. Whereas Levinas focuses our care on the other person, the Yijing's person of noble character has a wider calling, care, and responsibility: to act for others and "to equalize things and restore balance" (cheng wu ping shi 稱物平施). In recognizing the shared life of things, responsibility extends from the individual toward the other and to society and nature. The Yijing signals an ethical sensibility and interpretive art immanent to life while remaining open to its divergent possibilities.

The notion of an "ethics of nature" is problematic in Western moral theory. Levinas thoroughly differentiates the natural and the ethical, the immanent and the transcendent, maintaining that their identification would undermine ethics by turning it into ontology, reducing the good beyond being to the facticity and indifference of being. Western moral theorists from Kant to G. E. Moore support the separation of nature and ethics, arguing that relating them would be a dangerous confusion of "ought" and "is," normativity and factuality. G. E. Moore held that naturalistic ethics is incoherent because it cannot distinguish good and bad phenomena, which constitutes the very meaning of ethics. ${ }^{4}$

How does the moral dimension of the Yijing relate to its natural philosophy? How can the Yijing be both naturalistically based in the harmony of things as well as a normative and prescriptive appeal for a particular kind of action or responsive disposition orienting action? Can the ethical be understood as equalizing, balancing, and bringing into harmony? Does this entail that whatever happens is good? In the face of such questions, nature might be seen as the locus of the enactment of the ethical rather than an intrinsically alien, indifferent, and value-neutral realm. Ethics is after all ethos, a way of dwelling in the world. Ethical disposition or sensibility is an aspect of the way (dao 道) in early Chinese thought. In the Yijing, it is the way in which individuals comport themselves in changing circumstances and fortunes toward others and things, increasing or decreasing their well-being and harmony. Human behaviors and practices are part of the fabric of nature, which is nourishing and destructive, and heighten or lesson its patterns. Human activity partakes in the nourishment, maintenance, disordering, and destruction of things. Without the duality of fact and value, the Yijing involves a naturalistic yet interpretive ethics indicating the roles humans may play in responding to and nourishing life.

The interaction between interpreter and the Yijing's elements intimates ways of interpreting the cosmos, nature, and human behaviors through instructive examples and orienting models that can frame 
reflection and practice. It suggests a harmonizing of humans and nature, and hence an ecological and environmental balance: "The way of heaven is transformation; bringing each thing to life and sustaining it intermingled in great harmony" (qian dao bian hua, ge zheng xing ming, bao he da he 乾道變化, 各正性命, 保合大和). ${ }^{5}$ But this is not a vision that forgets the human and the individual, who throws the yarrow stalks and interprets the Yijing through its images and signs. Human agency is not detached from or irrelevant to life's ceaseless processes. Natural harmony is in turn acted upon and fulfilled by the person assuming responsibility, "the leader emerging from the people, who reiterates and heightens this natural harmony in the human world and lets peace reign" (shou chu shu wu, wan guo xian ning 首出庶物，萬國咸寧). ${ }^{6}$

UNIVERSITY OF MASSACHUSETTS LOWELL Lowell, Massachusetts

\section{ENDNOTES}

I would like to thank Chung-ying Cheng, Linyu Gu, and Dan Lusthaus for their comments and encouragement. I also wish to express my appreciation to Linyu Gu for her dedication in making both this issue of the Journal of Chinese Philosophy and the conference panel on which it is based possible. Earlier versions of the papers in this volume were presented at the 13th I-Ching World Conference in Wuxi, June 14-18, 2010.

1. On "onto-hermeneutics," see Chung-ying Cheng, "Inquiring into the Primary Model: Yi-Jing and Chinese Ontological Hermeneutics," in Comparative Approaches to Chinese Philosophy, ed. Bo Mou (Aldershot: Ashgate Publishing, 2003), 33-59; "OntoHermeneutical Vision and Analytic Discourse: Interpretation and Reconstruction in Chinese Philosophy," in Two Roads to Wisdom? Chinese and Analytic Philosophical Traditions, ed. Bo Mou (Chicago: Open Court Publishing, 2001), 87-129.

2. Yijing, Qian〈乾〉. Chinese text is from the Chinese Text Project: http://ctext.org/

3. Emmanuel Levinas, Totality and Infinity: An Essay on Exteriority (Dordrecht: Kluwer Academic Publishers, 1991), 22; Jill Robbins, Is It Righteous to Be? Interviews with Emmanuel Levinas (Stanford: Stanford University Press, 2001), 269.

4. G. E. Moore, Principia Ethica (Mineola: Dover Publications, 2004), 42.

5. Yijing, Qian〈乾〉.

6. Ibid. 